\title{
Ultraviolet-B radiation resistance of benthic diatoms isolated from tidal flats in the Dutch Wadden Sea
}

\author{
H. Peletier*, W. W. C. Gieskes, A. G. J. Buma \\ Dept of Marine Biology, Biological Centre RUG, PO Box 14, 9750 AA, Haren, The Netherlands
}

\begin{abstract}
Seven species representative of the benthic diatom community of the tidal flats in the Dutch Wadden Sea hardly differed in their sensitivity to ultraviolet-B radiation (UVBR). Some isolates had been cultured in the laboratory for up to $20 \mathrm{yr}$. Cell numbers of all species increased at a rate similar to unexposed cultures up to a DNA-weighted daily UVBR dose of $3.5 \mathrm{~kJ} \mathrm{~m}^{-2} \mathrm{~d}^{-1}$ (biologically effective dose, normalized at $300 \mathrm{~nm}$ ); only at higher UVB irradiance levels did the growth rate become reduced. No clear relationship between mean cell size and UVBR sensitivity was observed. The benthic diatoms that were tested are apparently adapted to the natural, high UVB irradiance incident at tidal flats during spring and summer Thus, even a sharp UVBR increase resulting from severe stratospheric ozone reduction would hardly affect tidal flat diatom communities by influencing cell division rate. In contrast, growth of representatives of the phytoplankton community was already seriously affected by doses that were 10 times lower. This is in agreement with their natural, low UVBR exposure
\end{abstract}

KEY WORDS: Benthic diatoms UVB sensitivity $\cdot$ Growth

\section{INTRODUCTION}

Benthic diatoms form a thin brown layer covering the sediment of tidal flat areas. These algal mats are of great ecological importance since they contribute considerably to primary productivity available to both the benthic and the pelagic community above the flats (Admiraal 1984). Another key function of benthic diatoms is that they stabilize the sediments in shallow seas by excretion of polymeric substances that stick particles together (Grant et al. 1986, Vos et al. 1988, Paterson 1989, Hoagland et al. 1993).

The benthic microalgal community usually consists of a large number of species. Tide and wave action, properties of the sediment or the flood water, and chemical and optical characteristics of the overlaying water column determine growth, production and species composition of the various communities (Admiraal 1984). The effect of ultraviolet-B radiation (UVBR) on

•E-mail: h.peletier@biol.rug.nl benthic diatoms of tidal flat areas has never been investigated properly (Kramer 1990), in spite of the fact that UVBR should be considered as a factor of great ecological significance. Benthic diatoms may be exposed to high levels of UVBR throughout the vegetative season, especially when growing on elevated tidal flats, where they are directly exposed to ultraviolet radiation during most of the tidal cycle.

In many macro- and microalgae, photosynthesis and growth are reduced upon exposure to UVBR (Worrest 1982, Cullen \& Lesser 1991, Ekelund 1991, Häder 1993, Larkum \& Wood 1993). When the level of UVB irradiation was increased, the species composition of phytoplankton in artificial microecosystems was seen to be affected (Worrest 1982, Bothwell et al. 1993). On the other hand, increased UVBR has had little effect on species diversity of Antarctic diatom communities over the past 20 yr (McMinn et al. 1994). UVBR may also affect the balance between primary producers and consumers of benthic communities (Bothwell et al. 1994). In the present study a selection of benthic diatom species 
representative of a tidal flat microalgal community was exposed to different levels of UVBR to test the effect of UVBR on growth rate reduction. A comparison in UVBR sensitivity with pelagic microalgae of the Dutch Wadden Sea and of the open waters of the bordering North Sea was set up to test the hypothesis that sedimentinhabiting diatoms are better adapted to UVBR than pelagic algae. In contrast to pelagic algae, that usually circulate vertically in the surface layer of open water and are therewith exposed to a variable light field, benthic diatoms in the intertidal mudflats of the Dutch Wadden Sea are exposed much more continuously to incident UVBR, even directly when emersed during low tide. Growth rate reduction as an indicator of UVBR stress was chosen since the most-studied effect on microalgae, photosynthetic rate reduction, which is usually measured during short incubations, may not reflect UVB stress suffered over more realistic longer time scales (i.e. in excess of several generations) that apply in field situations. Notice that it has been pointed out by Cullen \& Neale (1994) that short-term measurements of the rate of photosynthesis can easily be out of balance with growth; there is too little information on which to compare sensitivities of photosynthesis versus cell division (Cullen \& Neale 1994).

\section{MATERIALS AND METHODS}

All the benthic diatoms were isolated from tidal flats in the Ems-Dollard estuary, Wadden Sea, The Netherlands. Some of the species had been kept in the laboratory for several years without having been exposed to UVBR (Navicula salinarum, Nitzschia closterium, Amphiprora cf. paludosa, Stauroneis constricta, and Nitzschia thermalis), while others were isolated from the field just prior to the experiments (Nitzschia apiculata, $N$ salinarum, $N$. closterium, Amphiprora sp., Navicula flanatica). All the species tested are common in tidal microalgal mats of this region; they may reach monospecific occurrence at times (namely $N$. salinarum). Cultures were grown in artificial seawater medium supplied with nutrients, trace elements and vitamins as described by Admiraal \& Werner (1983). The 'old. cultures were maintained at a salinity of $33 \%$, while the freshly isolated species were kept at a salinity of $15 \%$ (local salinity at isolation). Cultures were grown at a photosynthetically active irradiance (PAR) level of $200 \mu \mathrm{E} \mathrm{m} \mathrm{m}^{-2} \mathrm{~s}^{-1}$ in an $8 \mathrm{~h}$ light $16 \mathrm{~h}$ dark cycle at a temperature of $12^{\circ} \mathrm{C}$. Experiments were carried out in polystyrene culture vessels or trays. Polystyrene is UVB transparent but eliminates the UVC that is emitted by the UVB lamp (Philips TL 12) used for the experiments (Fig 1) During the UVB treatments, cultures were illuminated from above by fluorescent tubes (Philips

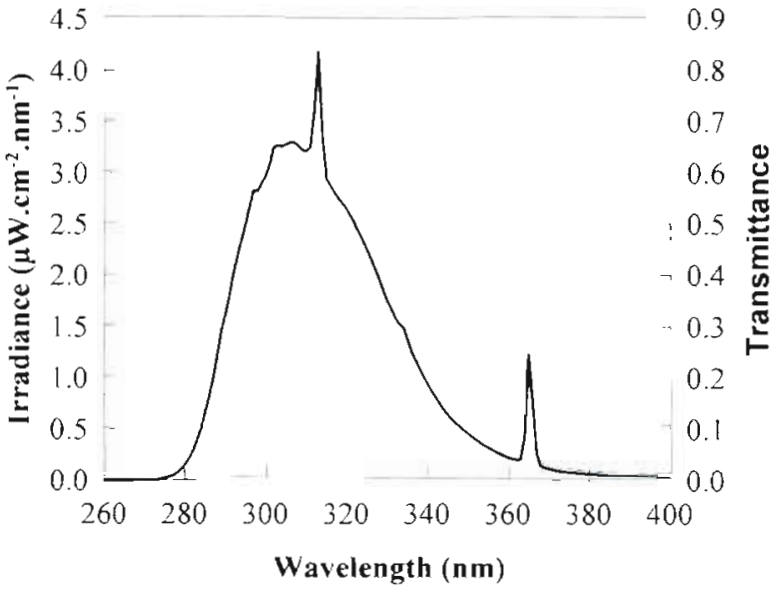

Fig. 1. Emission spectrum of the UVB lamp used (Philips TL 12 , bold line), measured with an Optronic OL752 spectroradiometer, and transmission spectrum (dotted line) of the UVB transparent perspex + polystyrene used for the experiments

TTD, $18 \mathrm{~W}$ ) to supply PAR; UVB was supplied from below. UVBR exposures were performed for $3 \mathrm{~h}$ a day in the middle of the PAR light period. Controls were placed on perspex plates that were non-transparant to UVBR (see also Steeneken et al. 1995).

The light spectrum (Fig. 1) received by the algae was thus determined by characteristics of both perspex and the polystyrene from the bottles or trays; transmission characteristics of both materials were measured with a Cary spectrophotometer (Cary, UV/Vis, Varian). Spectral emission (Fig. 1) of the UVB lamp was measured with an Optronics OL 752 spectroradiometer. Weighted daily UVBR doses were calculated from the spectrum received by the algae and the DNA action spectrum of Setlow, normalized at $300 \mathrm{~nm}$ (Setlow 1974). The daily weighted UVB doses (Biologically Effective, BED, normalized at $300 \mathrm{~nm}$ ) used in these experiments were 3.4 and $6.8 \mathrm{~kJ} \mathrm{~m}^{-2} \mathrm{~d}^{-1}$ (BED DNA300nm).

Since benthic diatoms attach to solid substrates, growth rate measurements were carried out in 2 ways. First, an algal suspension was divided over 2 trays, each containing 6 wells with a working volume of $7 \mathrm{ml}$ well ${ }^{-1}$. During these experiments 1 well was emptied completely by scraping the cells from the bottom of the well every other day. The whole volume of this well was counted.

The other method was to grow the cultures in $200 \mathrm{ml}$ polystyrene culture vessels. Twice a day the vessels were shaken vigorously to avoid strong attachment of the cells to the walls of the vessels. Every other day samples were taken from these vessels and counted. Experiments were carried out in triplicate. Cells were fixed with formaldehyde and counted in Neubauer counting chambers. Long-term growth rates were calculated from semi-log linear regression analysis of 
plots spanning several days of cell number increase. Reductions in growth were plotted against UVBR doses weighted by the DNA action spectrum and not with the absolute weighting functions of Cullen et al. (1992) because we wished to compare the benthic diatom response with that of phytoplankton exposed to natural UVBR sources (the data of Behrenfeld et al. 1993). UV effects on pelagic algae are described elsewhere (Buma et al. 1996b).

The cell size of the various species was determined by measuring the dimensions of the cells microscopically and by calculating the volume of simplified cell shapes such as discs or cylinders. Average cell volumes of the cultures were used throughout. Notice that these benthic diatoms are usually seen in valve view and hardly in girdle view. It is therefore not possible to distinguish any cell volume differences that might result from additional girdle band formation during growth.
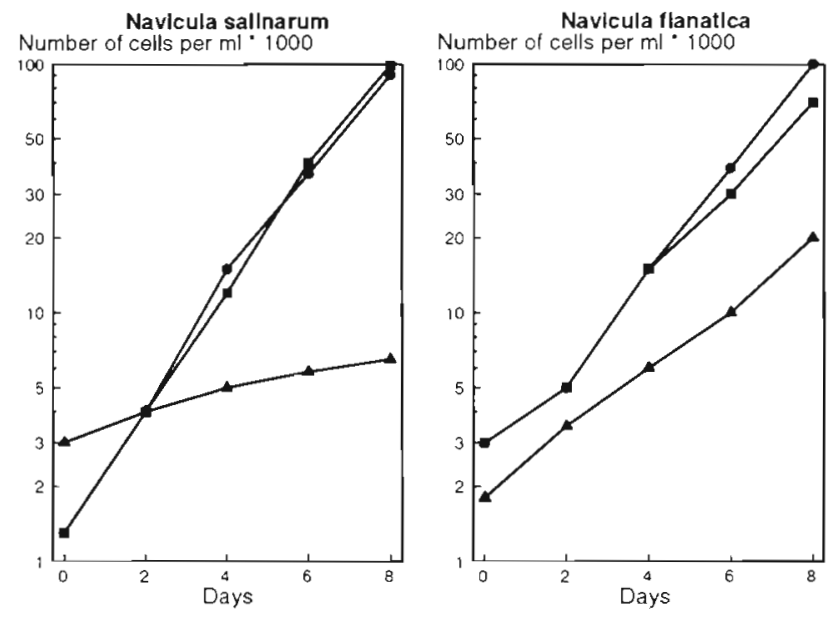

Fig. 2. Navicula salinarum and Navicula flanatica. Examples of growth curves during UVBR exposure for benthic diatoms grown in bottles. (1) $3.5 \mathrm{~kJ} \mathrm{~m}^{-2} \mathrm{~d}^{-1}$ (4) $6.8 \mathrm{~kJ} \mathrm{~m}^{-2} \mathrm{~d}^{-1}$; (•) reference

\section{RESULTS}

Both methods for determining growth rates of the diatoms showed identical results. Therefore only results of the culture bottle experiments are presented (Fig. 2). The cultures had to be exposed to a daily weighted UVBR dose of at least $3.4 \mathrm{~kJ} \mathrm{~m}^{-2}$ $\mathrm{d}^{-1}$ to establish UVBR induced growth rate reduction, with the exception of the freshly isolated Nitzschia closterium (which is also found in the plankton; see Table 1): only above this UVBR level was significant reduction observed.

Nitzschia apiculata and the freshly isolated strain of Navicula salinarum showed growth rate reduction only at $6.8 \mathrm{~kJ} \mathrm{~m}^{-2}$ $\mathrm{d}^{-1}$ (Fig. 3). Stauroneis constricta showed no significant growth rate reduction at all. No significant differences were found between cultures maintained in the lab for several years and the freshly isolated strains. Surprisingly, the 'old' strain of Nitzschia closterium (see 'Materials and methods') seemed less vulnerable than the freshly isolated strain (Fig. 3).

It has been suggested (Karentz et al. 1991, Bothwell et al. 1993) that UVBR sensitivity is related to cell size which influences protection of the cell nucleus through enhanced UVBR absorption by the cytoplasm. Since there is a large variation in size within the group of microalgae tested, UVBR sensitivity was also plotted against mean cellular volume as
Number of divisions day ${ }^{-1}$

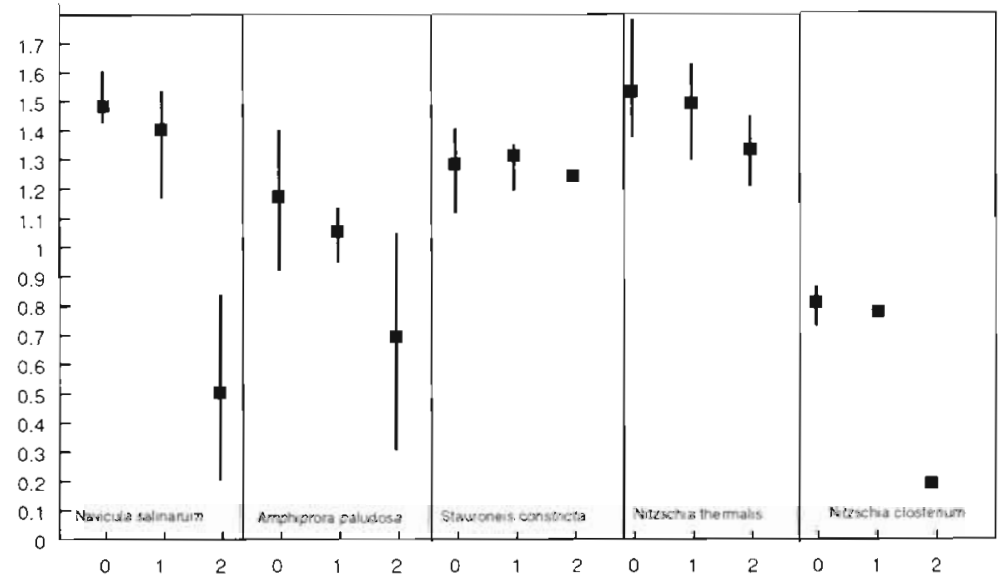

Number of divisions day ${ }^{-1}$

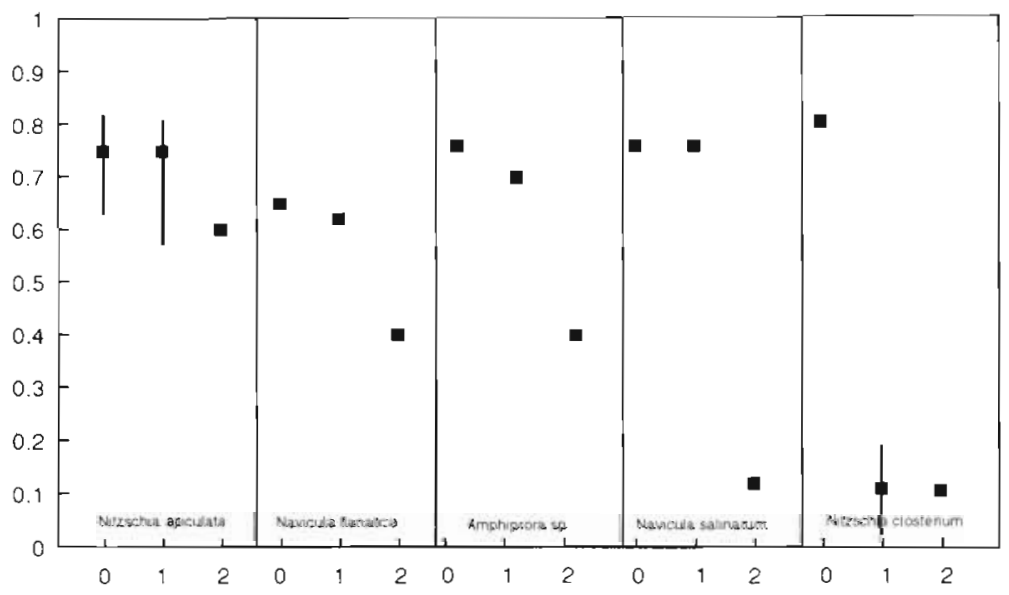

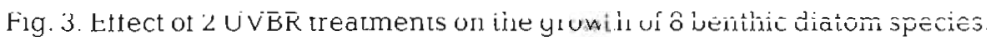
0 : reference; $1: 3.5 \mathrm{~kJ} \mathrm{~m}^{-2} \mathrm{~d}^{-1} ; 2: 6.8 \mathrm{~kJ} \mathrm{~m}^{-2} \mathrm{~d}^{-1}$ Vertical bars indicated upper and lower extreme of number of doublings $\mathrm{d}^{-1}$ between triplicate culture. 'Old' strains: top row; freshly isolated strains: bottom row 


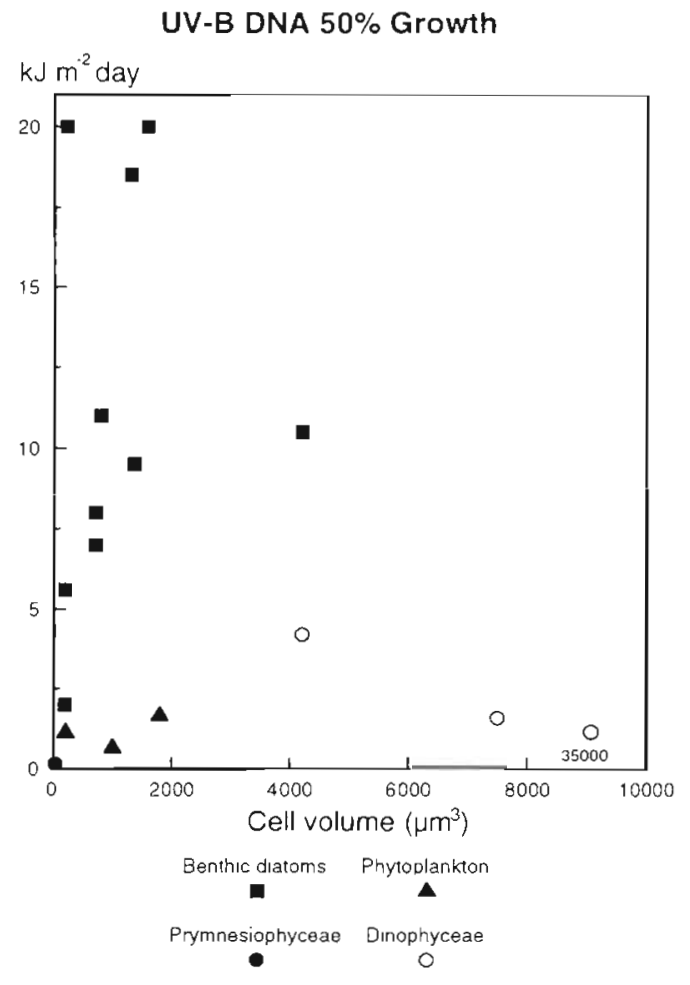

Fig. 4. Relation between UVBR sensitivity, expressed as the estimated daily UVB dose where $50 \%$ growth rate reduction occurs, and mean cellular volume in benthic and pelagic microalgae

measured during the experiments (Fig. 4). However, no clear relationship between mean cell size and UVBR sensitivity was observed (see Fig. 4).

\section{DISCUSSION}

The daily UVBR dose at which we still didn't record any growth reduction $\left(3.4 \mathrm{~kJ} \mathrm{~m}^{-2} \mathrm{~d}^{-1}\right)$ is well above natural UVBR levels in the Dutch Wadden Sea, even in summer. Behrenfeld et al. (1993) reported maximal daily UVBR doses (DNA weighted with Setlows action spectrum, normalized at $300 \mathrm{~nm}$ ) between 1 and $2 \mathrm{~kJ}$ $\mathrm{m}^{-2} \mathrm{~d}^{-1}$, calculated from incident irradiance at the Pacific Ocean's water surface in summer at mid-latitudes; this is roughly the level measured near the ground in our sampling area (data of RIVM, The Netherlands). In fact, the UVBR effect on growth that we measured was probably overestimated. At natural UVAR and PAR conditions resistance of algal species is probably even higher than at the light conditions offered in our experiments, where PAR was only $200 \mu \mathrm{mol} \mathrm{m} \mathrm{m}^{-2} \mathrm{~s}^{-1}$. Wavelengths in the UVAR and PAR range of the spectrum induce repair of damage due to UVBR stress (Karentz et al. 1994, Buma et al. 1995, 1996a); the formation of thymine dimers in nuclear
DNA after UVBR exposure can be reversed readily by simultaneous or subsequent exposure to UVAR and PAR (Buma et al. 1995, 1996a). These wavelengths were underrepresented in our experiments compared to the field situation: PAR intensity was definitely lower than incident natural PAR irradiances on Dutch tidal flats during summer, which are up to $2500 \mu \mathrm{mol}$ $\mathrm{m}^{-2} \mathrm{~s}^{-1}$. Our UVBR lamp did emit some UVAR, but (see Fig. 1) at a much lower level compared with natural UVAR. The effect of UVAR on growth rate of a mat forming cyanobacterium was also reported by Quesada et al. (1995). Data presented by Jokiel \& York (1984) showed that rapid adaptation of phytoplankton to extremely high levels of solar UVAR and PAR is also possible.

The benthic diatoms tested did differ in their UVBR sensitivity but they all had a very high UVBR resistance. Nitzschia closterium was the exception but this species is also found abundantly in the water column. No differences were found between cultures kept in the laboratory for many years (a stock culture of Stauroneis constricta was even kept in the laboratory for $20 \mathrm{yr}$ ) and freshly isolated cultures. Apparently, resistance against high UVBR levels is not readily lost: it is a very stable characteristic.

It is not known what causes the high UVBR resistance in these microalgae. In future work we will analyse defense mechanisms such as pigmentation and DNA damage repair (Buma et al. 1996a). Indeed, it is possible that they form pigments that absorb specifically in the UVBR region of the spectrum (mycosporine-like amino acids, Carreto et al. 1990). Alternatively, the species may have acquired the very efficient UV induced damage repair system described for planktonic microalgae by Buma et al. (1995), possibly through rapid synthesis of enzymes involved in photoenzymatic repair. The acquisition of highly efficient repair mechanisms of benthic diatoms is probably related to the natural exposure to intense UVBR.

The UVBR response found here differs greatly from the UVBR response found in pelagic algae (Table 1). The pelagic diatoms and dinoflagellates and the prymnesiophyte Emiliania huxleyi that we tested under similar conditions showed much higher UVBR vulnerability; $E$. huxleyi showed complete growth inhibition already at $0.5 \mathrm{~kJ} \mathrm{~m}^{-2} \mathrm{~d}^{-1}$ (Buma pers. comm.). In Table 1, the UVBR sensitivity is expressed as the daily weighted UVBR dose where $50 \%$ growth reduction occurs (calculated from semi-log linear regression analysis). Although these are very rough estimates, because dose-response relationships are non-linear, the differences are large enough to make the figures reliable.

UVBR has probably been a natural selective factor in these microalgal communities; it has, in this aspect con- 
Table 1 Comparison of UVBR sensitivity, expressed as the estimated daily UVBR dose where $50 \%$ growth rate reduction occurs, in several benthic species and algae isolated from pelagic environments (data of pelagic algae taken from own experiments under similar. UVBR and PAR conditions)

\begin{tabular}{|lr|}
\hline Species & $\begin{array}{r}50 \% \text { growth reduction } \\
\left(\mathrm{J} \mathrm{m}^{-2} \mathrm{~d}^{-1}\right)\end{array}$ \\
\hline Benthic species & \\
Navicula salinarum & \\
Navicula salinarum 2 & 8000 \\
Navicula flanatica & 7000 \\
Nitzschia thermalis & 11000 \\
Amphiprora paludosa & 20000 \\
Amphiprora sp. & 10500 \\
Stauroneis constricta & 9500 \\
Nitzschia closterium (b1) & 20000 \\
Nitzschia closterium (b2) & 5600 \\
Pelagic species & 2000 \\
Nitzschia closterium (p1) & \\
Cyclotella nana & 800 \\
Thalassiosira nordenskioldii & 660 \\
Prorocentrum micans & 1660 \\
Alexandrium tamarense & 1600 \\
Emiliania huxleyi & 1250 \\
& 150 \\
\hline
\end{tabular}

tributed to the dominance of these species in algal mats because of their ability to outcompete more UVBRsensitive species. The specific environmental conditions that determine the density and species composition of benthic estuarine diatom populations are not easy to determine since they are only one constituent of an ecosystem; this makes it impossible to predict if and how the composition of the system will change with an increase in UVBR levels. Moreover, very little is known about species-specific effects of UVAR and visible light on the repair of benthic diatoms. However, we suggest here that it is unlikely that UVBR levels will cause more UVBR stress in these communities even when ozone reduction continues at its present rate during the coming decades: in the worst case scenarios of ozone depletion the increase in daily UVBR exposure will certainly remain below the irradiance of $3.5 \mathrm{~kJ} \mathrm{~m}^{-2} \mathrm{~s}^{-1}$ and higher at which we started to observe negative effects on cell number increase.

Acknowledgements. We thank A. Veen (NIOO, Nieuwersluis, The Netherlands) for spectroradiometer measurements and Prof. W. Admiraal for critical reading of the manuscript. We are grateful to $\mathrm{J}$. J. Cullen for many helpful comments. This project was financed by the Dutch NRP (project number 851054)

\section{LITERATURE CITED}

Admiraal W (1984) The ecology of estuarine sediment-inhabiting diatoms. In: Round FE, Chapman DJ (eds) Progress in phycological research, Vol 3. Biopress, Bristol, p 269-322
Admiraal W, Werner D (1983) Utilization of limiting concentrations of orthophosphate and production of extracellular organic phosphates in cultures of marine diatoms. J Plankton Res 5(4):495-513

Behrenfeld M, Hardy J, Gucinski H, Hanneman A, Lee H II, Wones A (1993) Effects of ultraviolet-B radiation on primary production along latitudinal transects in the South Pacific Ocean. Mar Environ Res 35:349-63

Bothwell ML, Sherbot DMJ, Pollock CM (1994) Ecosystem response to solar ultraviolet radiation: influence of trophiclevel interactions. Science 265:97-100

Bothwell ML, Sherbot D, Roberge AC, Daley RJ (1993) Influence of natural ultraviolet radiation on lotic periphytic diatom community growth, bıomass accrual and species composition: short-term versus long-term. J Phycol 29: $24-35$

Buma AGJ, Van Hannen EJ, Veldhuis MJW, Gieskes WWC (1996a) UV-B induces DNA damage and DNA synthesis delay in the marine diatom Cyclotella sp. Proc of the Second Algal Photobiology. Workshop, Malaga, Oct 1994. Scientia Mar 60 (Suppl 1):101-105

Buma AGJ, Van Hannen EJ, Veldhuis MJW, Roza L, Gieskes WWC (1995) Monitoring UV-B induced DNA damage in individual diatom cells by immunofluorescent thymine dimer detection. J Phycol 31:314-321

Buma AGJ, Zemmelink HJ, Sjollema K. Gieskes WWC (1996b) UVB radiation affects protein and photosynthetic pigment content, volume and ultrastructure of marine diatoms. Mar Ecol Prog Ser (in press)

Carreto Jl, Carigan MO, Daleo G, Marco SGD (1990) Occurrence of microsporine-like amino-acids in the red-tide dinoflagellate Alexandrium excavatum: UV-protective compounds? J Plankton Res 12:909-921

Cullen JJ, Lesser MP (1991) Inhibition of photosynthesis by ultraviolet radiation as a function of dose and dosage rate: results for a marine diatom. Mar Biol 111:183-190

Cullen JJ, Neale PJ (1994) Ultraviolet radiation, ozone depletion, and marine photosynthesis. Photosynth Res 39 $303-320$

Cullen JJ, Neale PJ, Lesser MP (1992) Biological weighting function for the inhibition of phytoplankton photosynthesis by ultraviolet radiation. Science 258:646-650

Ekelund NGA (1991) The effects of UV-B radiation on dinoflagellates. Plant Physiol 138:274-278

Grant J, Bathmann UV, Mills EL (1986) The interaction between benthic diatom films and sediment transport Estuar Coast Shelf Sci 23:225-38

Häder DP (1993) Risks of enhanced solar ultraviolet radiation for aquatic ecosystems. Prog Phycol Res 9:1-45

Hoagland KD, Rosowski JR, Gretz MR, Roemer SC (1993) Diatom extracellular polymeric substances: function, fine structure, chemistry, and physiology. J Phycol 29: $537-566$

Jokiel PL, York RH Jr (1984) Importance of ultraviolet radiation in photoinhibition of microalgal growth. Limnol Oceanogr 29(1):192-199

Karentz D (1994) Ultraviolet tolerance mechanisms in Antarctic marine organisms. In: Weiler CS, Penhale PA (eds) Ultraviolet radiation in Antarctica: measurements and biological effects. Antarctic research series 62:93-110. American Geophysical Union

Karentz D, Cleaver JE, Mitchell DL (1991) Cell survival characteristics and molecular responses of Antarctic phyto-

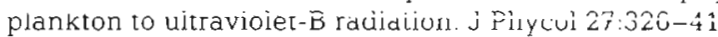

Kramer KJM (1990) Effects of increased solar UV-B radiation on coastal marine ecosystems: an overview. In: Beukema JJ. Wolff WJ, Brouns JJMW (eds) Expected effects of cli- 
matic change on marine coastal ecosystems. Kluwer Academic Publishers, Dordrecht, p 195-210

Larkum AWD, Wood WF (1993) The effect of UV-B radiation on photosynthesis and respiration of phytoplankton, benthic macroalgae and seagrasses. Photosynth Res 36:1723

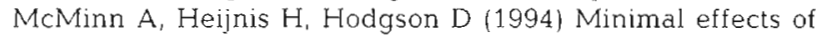
UVB radiation on Antarctic diatoms over the past 20 years. Nature 370:547-549

Paterson DM (1989) Short-term changes in the erodibility of intertidal cohesive sediments related to the migratory behavior of epipelic diatoms. Limnol Oceanogr 34:223-234

Quesada A, Mouget JL, Vincent WF (1995) Growth of Antarctic cyanobacteria under ultraviolet radiation: UVA counteracts UVB inhibition. J Phycol 31:242-248

Setlow RB (1974) The wavelengths in sunlight effective in

This article was submitted to the editor producing skın cancer: a theoretical analysis. Proc Nat Acad Sci USA 71:3363-3366

Steeneken SF, Buma AGJ, Gieskes WWC (1995) Changes in transmission characteristics of polymethylmethacrylate and cellulose (III) acetate during exposure to ultraviolet light. Photochem Photobiol 61(3):276-280

Vos PC, de Boer PL, Misdorp R (1988) Sediment stabilization by benthic diatoms in intertidal sandy shoals; qualitative and quantitative observations. In: de Boer PL, van Gelder A (eds) Tide-influenced sedimentary environments and facies. D Riedel Pub Co, Dordrecht, p 511-526

Worrest RC (1982) Review of literature concerning the impact of UV-B radiation on marine organisms. In: Calkins J (ed) The role of solar radiation in marine ecosystems. Plenum Press, New York, p 429-457

Manuscript first received: September 1, 1995 Revised version accepted: December 28, 1995 